\title{
Prevalence of ovarian tumours among ovarian mass lesions in Gajra Raja Medical College, Gwalior, India
}

\author{
Jyoti Bindal, Sangeeta Bankey*
}

Department of Obstetrics and Gynecology, G. R. Medical College, Gwalior, Madhya Pradesh, India

Received: 21 June 2017

Accepted: 19 July 2017

\section{*Correspondence:}

Dr. Sangeeta Bankey,

E-mail: shinchan.bankey@gmail.com

Copyright: (C) the author(s), publisher and licensee Medip Academy. This is an open-access article distributed under the terms of the Creative Commons Attribution Non-Commercial License, which permits unrestricted non-commercial use, distribution, and reproduction in any medium, provided the original work is properly cited.

\begin{abstract}
Background: Ovarian tumor is one of the most common gynecological tumors seen in female although there are different types of ovarian tumor but epithelial ovarian cancer is the fifth most common cause of cancer death in women. It is often called the "silent killer" because the disease is not often detected until it reaches an advance stage. Methods: This observational study conducted on 130 patients from February 2015 to March 2017 in the Department of Obstetrics and Gynaecology in Gajra Raja Medical College, Gwalior. Clinical details of the patients included age, gynaecological and obstetric history, presenting symptoms, and surgery details. Histopathological reporting was done at our Pathology department.

Results: Out of total 130 patients with ovarian tumours studied $49.2 \%$ were $>60$ years of age group, most of them were nullipara $(53.8 \%), 54.6 \%$ with ovarian tumours presented after one-year development of symptoms. most of the symptoms were vague and nonspecific. Benign tumours were the most prevalent $(79.2 \%), 19.2 \%$ were malignant tumours and $1.5 \%$ were borderline. Histological pattern of distribution of ovarian tumour shows that most of ovarian tumour were surface epithelial tumour (72 patients) followed by germ cell tumour (58 patients). Age wise distribution of study population showed that most of the surface epithelial tumour were more common in $3^{\text {rd }}$ to $5^{\text {th }}$ decade while most of germ cell tumour were more frequent in $2^{\text {nd }}$ and $3^{\text {rd }}$ decade.

Conclusions: For better prognosis and patient survival, early detection and treatment is mandatory, which may reduce mortality. There is need to increase awareness of population. Abdominal and pelvic bimanual examination should be carried out in every patient presenting with gynecological problem. Appropriate investigations in post-menopausal women in early period to diagnose the disease at an early stage.
\end{abstract}

Keywords: Germ cell tumour, Ovarian tumour, Surface epithelial tumour

\section{INTRODUCTION}

Ovarian tumor is one of the most common gynecological tumors seen in female although there are different types of ovarian tumor but epithelial ovarian cancer is the fifth most common cause of cancer death in women. ${ }^{1}$ It is often called the "silent killer" because the disease is not often detected until it reaches an advance stage. Due to its anatomical location, such ovarian tumors may remain unnoticed for a long period of time. ${ }^{2,3}$ Ovarian cancer usually affects the age of 65 years or older more frequently than younger women, they are not always malignant, but, the incidence of malignancy is about $15 \%$ $-25 \%$ in different parts of the world. ${ }^{4}$ These tumors behave in diverse ways and are generally not detected until they get large size. ${ }^{5}$ Ovarian tumors may be cystic or solid in consistency. Most of the benign tumors are cystic but $80 \%$ of solid ovarian tumors are malignant. ${ }^{3,6}$

There are a number of risk factors associated with their origin. None of these has been yet proved except for age and parity. The relative risk for ovarian malignancy 
increases significantly after the age of 40 years. ${ }^{7,8}$ An early menarche and late menopause are associated with an increased risk. Use of oral contraceptive is associated with a reduced risk of benign ovarian neoplasma. ${ }^{9,10}$ Common symptoms include abdominal distension, abdominal and pelvic pain, and dyspepsia and also increased the frequency of urine. Family history of ovarian and breast cancer has strong link and considers as major risk factor for ovarian cancer. ${ }^{11-13}$

One theory is that ovarian carcinoma arises from endometriosis; it is the presence of endometrial tissue rather than uterus. ${ }^{14}$

\section{METHODS}

This observational study conducted on 130 patients from February 2015 to March 2017 in the Department of Obstetrics and Gynaecology in Gajra Raja Medical College, Gwalior.

All cases with ovarian mass lesions treated surgically were included in the study. All patients who refused to participate or opted for conservative treatment. Similarly, incomplete filled proforma or patient lost to follow up with histology reports are excluded from the study.

The diagnostic evaluation was done with investigations for exclusion of malignancy with USG, tumour markers, CT and MRI wherever indicated. Clinical details of the patients included age, gynaecological and obstetric history, presenting symptoms, and surgery details. Histopathological reporting was done at our Pathology department.

The histological characterisation of ovarian tumour was done according to World Health Organization Classification of Ovarian tumours.

\section{RESULTS}

Table 1: Frequency of age group of study participants.

\begin{tabular}{|lll|}
\hline Age group (yrs) & No. of patients & $\%$ \\
\hline$\leq 30$ & 18 & 13.8 \\
\hline $31-40$ & 8 & 6.2 \\
\hline $41-50$ & 11 & 8.5 \\
\hline $51-60$ & 29 & 22.3 \\
\hline$>60$ & 64 & 49.2 \\
\hline Total & 130 & 100 \\
\hline
\end{tabular}

Out of total 130 patients with ovarian tumours, most of patients $49.2 \%$ were $>60$ years of age while $6.2 \%$ in the age group of $30-40$ years.

Out of total 130 patients of ovarian tumours, $53.8 \%$ were nullipara while $25.4 \%$ were primipara and $20.8 \%$ were multipara.
Table 2: Parity of women.

\begin{tabular}{|lll|}
\hline Age group (yrs) & No. of patients & $\%$ \\
\hline Nullipara & 70 & 53.8 \\
\hline Primipara & 33 & 25.4 \\
\hline Multipara & 27 & 20.8 \\
\hline Total & 130 & 100 \\
\hline
\end{tabular}

Table 3: Duration of symptoms.

\begin{tabular}{|lll|}
\hline Duration of symptoms & No. of patients & $\%$ \\
\hline$<6$ months & 19 & 14.6 \\
\hline 6 months - 1 year & 40 & 30.8 \\
\hline$>1$ year & 71 & 54.6 \\
\hline Total & 130 & 100 \\
\hline
\end{tabular}

Above Table shows that, $54.6 \%$ with ovarian mass presented after one-year development symptoms for delay were non-specific symptoms, inadequate health care system, omission of pelvic examination of presentation, illiteracy and poverty.

Table 4: Frequency of various symptoms of study participants.

\begin{tabular}{|lll|}
\hline Symptoms & No. of patients & $\%$ \\
\hline Asymptomatic & 18 & 13.8 \\
\hline Nausea & 22 & 16.9 \\
\hline Vomiting & 4 & 3.1 \\
\hline Weight gain & 9 & 6.9 \\
\hline Abdominal mass & 49 & 37.7 \\
\hline Increased urinary frequency & 28 & 21.5 \\
\hline Total & 130 & 100 \\
\hline
\end{tabular}

Early diagnosis of the ovarian cancer is a challenge to the gynaecologist due to fact that symptoms in early disease were vague symptom and non-specific.

Table 5: Type of ovarian tumour.

\begin{tabular}{|lll|}
\hline Type & No. of patients & $\%$ \\
\hline Borderline & 2 & 1.5 \\
\hline Benign & 103 & 79.2 \\
\hline Malignant & 25 & 19.2 \\
\hline Total & 130 & 100 \\
\hline
\end{tabular}

Out of total 130 patients of ovarian tumours, $79.2 \%$ were benign, $19.2 \%$ were malignant and only $1.5 \%$ were borderline.

Histological pattern of distribution of ovarian tumour shows that most of ovarian tumour were surface epithelial tumour (72 patients) followed by germ cell tumour (58 patients).

Age wise distribution of study population showed that most of the surface epithelial tumour were more common in $3^{\text {rd }}$ to $5^{\text {th }}$ decade while most of germ cell tumour were more frequent in $2^{\text {nd }}$ and $3^{\text {rd }}$ decade. 
Table 6: Histological pattern of ovarian tumours.

\begin{tabular}{|lcccc|}
\hline \multicolumn{1}{c}{ Diagnosis } & Benign & Borderline & Malignant & Total \\
\hline Surface Epithelial Tumour & 52 & 2 & 18 & 72 \\
\hline Serous tumour & 34 & - & 9 & 43 \\
\hline Mucinous tumour & 14 & 2 & 8 & 24 \\
\hline Endometrioid tumour & - & - & 1 & 1 \\
\hline Malignant mixed mullerian tumour & - & - & - & - \\
\hline Brenner tumour & 1 & - & - & 1 \\
\hline Mixed epithelial tumour & 2 & - & - & 2 \\
\hline Sex Cord-Stromal Tumour & - & - & - & - \\
\hline Adult granulosa cell tumour & - & - & - & - \\
\hline Fibroma & 1 & - & - & 1 \\
\hline Thecoma & - & - & - & - \\
\hline Sclerosing stromal tumour & - & - & - & - \\
\hline Germ Cell Tumour & 49 & - & 9 & 58 \\
\hline Dysgerminoma & - & - & 2 & 2 \\
\hline Yolk sac tumour & - & - & - & - \\
\hline Mature cystic teratoma & 48 & - & - & 48 \\
\hline Ovarii & 1 & - & - & 1 \\
\hline Immature teratoma & - & - & 7 & 7 \\
\hline SCC arising from a dermoid cyst & - & - & - & - \\
\hline Malignant mixed germ cell tumour & - & - & - & - \\
\hline Grand Total & 101 & 02 & 27 & 130 \\
\hline
\end{tabular}

Table 7: Frequency of different classes of ovarian tumours in different age groups.

\begin{tabular}{|c|c|c|c|c|c|c|c|c|c|}
\hline Classes of tumors & Total & Types & $<20$ & $20-29$ & $30-39$ & $40-49$ & $50-59$ & $\geq 60$ & Total \\
\hline \multirow{2}{*}{ Surface epithelial } & \multirow{2}{*}{72} & Benign & 2 & 8 & 13 & 9 & 11 & 9 & 52 \\
\hline & & Malignant & 0 & 2 & 2 & 5 & 8 & 1 & 18 \\
\hline \multirow{2}{*}{ Germ cell } & \multirow{2}{*}{58} & Benign & 4 & 28 & 13 & 3 & 1 & - & 49 \\
\hline & & Malignant & 1 & 4 & 1 & 1 & - & - & 7 \\
\hline
\end{tabular}

\section{DISCUSSION}

The ovary is a dynamic complex structure in embryology, histology, steroidogenesis, with its potential for malignancy, with its different components like germ cells, follicular cells and mesenchymal tissue each having different capability to form various tumours.

Present study reveals that the presentation of ovarian tumours is variable. Common symptoms were abdominal mass, pelvic/abdominal pain. Other symptoms are dyspepsia, urinary frequency and urgency, loss of weight and ascites, which are more common in malignant tumours. These findings are in accordance to other studies.

In this study, $19.6 \%$ patients were asymptomatic while Muhabat Q et al studied $19.6 \%$ patients were asymptomatic. $^{15}$

In present study, $53.8 \%$ women who had ovarian tumor were nullipara while $20.8 \%$ multipara. However, in study conducted by Khan I, at KEMU/Lady Willington hospital, $58.15 \%$ women who had ovarian tumor were multipara. ${ }^{16}$ In another population based case control study, Ernstaff $\mathrm{T}$ et al. found that risk of ovarian tumors was higher in multiparous, a woman which is comparable to results of present study. ${ }^{17}$

In current study, $54.6 \%$ presented with ovarian tumor after 1 year of development of symptoms reason of delay were non-specific symptoms, inadequate health care system, omission of pelvic examination at presentation, illiteracy and poverty. Muhabat Q studied 43\% patients were presented with ovarian tumour after $>1$ year of symptoms. $^{15}$

In present study, benign neoplasma were $79.2 \%$, borderline $1.5 \%$ and malignant neoplasia were $19.2 \%$. Similarly, in study conducted by Yogambal $\mathrm{M}$ et al, they studied out of 402 patients with ovarian mass, benign neoplasma were $78.6 \%$, borderline $0.75 \%$ and malignant neoplasia were $20.65 \% .{ }^{18}$ This study correlates with present study. Other study done by Makwanal $\mathrm{H}$ et al, they found benign neoplasma were $77.14 \%$, borderline 
$3.57 \%$ and malignant neoplasia were $19.29 \% .{ }^{19}$ This study also correlates with our study.

In present study surface epithelial tumors were commonest, followed by germ cell tumors.

\section{CONCLUSION}

Most of the tumour were of surface epithelial tumour. Mature cystic teratoma was most common benign germ cell tumour. While serous cell carcinoma was commonest malignancies. Benign tumour were more common than malignancies in all age groups. Malignant surface epithelial tumour were mostly seen after 4 decades while malignant germ cell tumour were observed in a younger age group. For better prognosis and patient survival, early detection and treatment is mandatory, which may reduce mortality. There is need to increase awareness of population. Abdominal and pelvic bimanual examination should be carried out in every patient presenting with gynecological problem. Appropriate investigations in post-menopausal women in early period to diagnose the disease at an early stage.

Funding: No funding sources Conflict of interest: None declared

Ethical approval: The study was approved by the Institutional Ethics Committee

\section{REFERENCES}

1. Mandiac A, Nincic D, Vujkov T. Ovarian Epithelial Carcinoma; a Malignant Disease Sparing No Age Group. Medicinski Pregled. 2003;56:157-61.

2. Saler E, Eliyahaus S, Leleg D, Tsabari A. Laparoscopic Management of Adenexal Cystic Mass in Post Memopausal Women. Obstet Gynecol. 1994;83:594-6.

3. Wasim T, Majrooh A, Siddiq S. Comparison of Clinical Presentation of Benign and Malignant Ovarian Tumors. J Allama Iqbal Medic Coll. 2009;59:18-21.

4. Naheed I, Malik S, Shaukat MS, Review of Ovarian Tumors. JRMC. 2001;7:180-2.

5. Zafar FA, Fazil A, Asifa A, Karim A, Akmal N. Clinical Manifestations of Benign Ovarian Tumors. JLUMHS. 2005;11:258-9.

6. Chohan A. Benign Diseases of Ovary. In: Chohan, A., Fundamentals of Gynecolgy, Mar Publication, Lahore. 2005;281.

7. Greenlee RT, Hill Harmone MB, Murray T, Theen M. Cancer Statistic 2001. CA: A Cancer J Clinicians. 2001;51:15.
8. Tay SK, Tan YY. Risk Factors and a Risk Scoring System for the Prediction of Malignancy in Ovarian Cysts. Australian N Z J Obstet Gynecol. 1992;32:341-5.

9. Gabra H. Epithelial Ovarian Cancer. Dewhurst's Textbook of Obstetrics and Gynecology. $7^{\text {th }}$ Edition, Wiley-Blackwell, London; 2007;625-35.

10. Booth M, Beral V, Machonochie N, Carpenter L, Scott C. A case control study of benign tumors. J Epidemiol Comm Health. 1992;46:528-31.

11. Goff BA, Mandel LS, Melancon CH, Muntz HG. Frequency of symptoms of ovarian cancer in women presenting to primary care clinics. JAMA. 2004;291:2705-12.

12. Rufford BD, Jacobs IJ, Memon U. Feasibility of screening for ovarian cancer using symptoms as selection criteria. BJOG. 2007;114:59-64.

13. Shen-Gunther J, Mannel RS. Ascites as a Predicator of ovarian malignancy. Gynecol Oncol. 2002;87:7783.

14. Ness RB, Cottreau C. Possible role of ovarian epithelial inflammation in ovarian cancer. J Natl Cancer Inst. 1999;91:1459-67.

15. Muhabat Q, Waheed F, Waqarunissa, Jabeen N. Clinical presentation of ovarian tumors. Open $\mathbf{J}$ Obstet Gynecol. 2016;6:205-9.

16. Khan I, Shezadi N. Prospective study of ovarian tumors clinical pattern and their management at Lady Willingdon Hospital. Pak J Med Health Sci. 2010;4:159-62.

17. Titus-Ernstoff L, Perez K, Cramer DW, Harlow BL, Baron JA and Greenberg ER. Menstrual and re productive factors in relation to ovarian cancer risk. Br J Cancer. 2001;84:714-21.

18. Yogambal M, Arunalatha $\mathrm{P}$, Chandramouleeswari K, Palaniappan V. Ovarian tumours-Incidence and distribution in a tertiary referral center in south India. IOSR J Dental Med Sci. 2014;13(2):74-80.

19. Makwana H, Maru A, Lakum N, Agnihotri A, Trivedi N, Joshi J. The relative frequency and histopathological pattern of ovarian masses-11 year study at tertiary care centre. Int J Medic Sci Public Health. 2014;3(1):81-4.

Cite this article as: Bindal J, S Bankey S.

Prevalence of ovarian tumours among ovarian mass lesions in Gajra Raja Medical College, Gwalior, India. Int J Reprod Contracept Obstet Gynecol 2017;6:3907-10. 